\title{
THE IDENTITY OF THE ARTISTS INVOLVED IN VESALIUS'S FABRICA 1543
}

by

\section{FRANCISCO GUERRA}

\section{INTRODUCTION}

ANDREAS Vesalius failed to mention by name the illustrators of his De humani corporis fabrica (1543) and no marks can be found on the woodcuts which help to identify the draughtsman or the engraver. Although the name of Jan Stevens, better known as J. S. van Calcar [1499-1546] appeared in the colophon of the Tabulae anatomicae sex, 1538, the analysis by O'Malley (1964) of the production of the Fabrica casts doubts upon the idea that Jan Steven van Calcar also made the drawings for the Fabrica. Vesalian scholars, on the other hand, have never made any attempt to identify the engraver. Four centuries after Vesalius's death the identity of the Fabrica's illustrators is, therefore, still far from established, and a perusal of Ivins' essay (1952) tends to make a solution seem more unlikely. Recent studies superseding Choulant's (1852) classic monograph are discarded by Ivins; Cushing's information (1942) on grounds of misinterpreting technical facts, and the study by Singer and Rabin (1946) on account of their uncritical statements.

The problem is far from being a literary quest because historians rank Vesalius's Fabrica 1543 as the great medical achievement of the Renaissance, and the fame of this book was very much dependent on its breakthrough in anatomical illustration. The artists of that period were devoted to anatomical studies of their own for aesthetic reasons, and an unbiased study of this problem might acknowledge in fair terms the credit due to Vesalius without overlooking the credit due to the artists of the Fabrica.

Evidence is now offered bearing upon the identity of the engravers of the Fabrica, which also confirms the role of Jan Steven van Calcar in the drawings. But it must be acknowledged that the pursuit of this research has proved to be an exercise in rectifying references from sources hitherto accepted as consistent and reliable.

VALVERDE'S TRAIL

The silence of Vesalius about his co-workers resembles the behaviour of his contemporary, the Spanish anatomist Juan de Valverde de Amusco, who published an Historia de la composición del cuerpo humano at Rome in 1556. Of the 253 Valverdean illustrations only two have the initials N.B. used by the engraver Nicolas Beatrizet [1515-c.1589] and it has been shown elsewhere (Guerra, 1967) that the author of the original drawings, Gaspar Becerra [1520-1570] could only be identified from secondary evidence. However, during the search for Valverde's artists, a statement came to light giving the name of the Fabrica's engraver. The discovery occurred because Becerra, like many of the Renaissance artists, excelled not only in painting but in sculpture and architecture, and one of his best biographical sources is the work on Spanish architects by Eugenio Llaguno y Amírola [c. 1730-1799], a high-ranking 


\section{Franciso Guerra}

civil servant under Charles III, King of Spain. Llaguno's book has the unusual characteristic among Spanish works of supporting its text with notes and generous transcripts of the original documents. Furthermore Llaguno's Noticia de los arquitectos ... de España (1829) was published posthumously with annotations and corrections by his learned colleague Juan Agustín Ceán Bermudez [1749-1829]. Becerra's biography appears in Vo. II, pp. 106-112 with footnotes by both Llaguno and Ceán. One of Llaguno's notes** in Vol. II, p. 107, reads:

(**) Vasari in the life of Marco Antonio says: that these figures were drawn by Juan de Calcare or Calker, Flemish, most excellent painter a pupil of Titian, and that they were carved by Francesco Marcolino de Forli: they are highly appreciated; and Mons. Bottari adds in a note, that someone attributes them to Titian himself.

This note by Llaguno immediately raises the question whether Vasari was properly quoted or his meaning correctly interpreted. Furthermore, it makes us question whether Vasari was in a position to have first-hand information about any work on the Fabrica which could have been carried out by Vesalius, van Calcar and Marcolini between the years 1539 and 1542. Also, whether Francesco Marcolini was the only Venetian engraver with the opportunity and the means to produce the woodcuts of the Fabrica during the same period.

\section{VASARI'S TESTIMONY}

It is clear that Llaguno was referring to Giorgio Vasari the Elder's [1511-1574] edition of Le Vite de piu eccellenti, scultori, e architettori . . correte da molti errori $e$ illustrate con note (1759-1760) by Monsignor Giovanni G. Bottari [1689-1775], the former librarian at the Vatican. Vasari's mention of Vesalius, Jan Steven van Calcar, Marcolini and Valverde, all in the same sentence, did not appear in the first edition of Le vite . . ., published in Florence (1550) but figured for the first time when Vasari wrote about engravers in the enlarged second edition of Florence (1568) from which Monsignor Bottari prepared the annotated Roman edition (1759-1760). The extraordinary fact is that Llaguno quoted a phrase in Vasari known to every Vesalian scholar, but in doing so he followed the loose grammatical sequence common to earlier Spanish and Italian writers, and not the rigorous literary style of our days. Thus Llaguno qualified the latter part of the sentence in which Vasari refers to the Vesalian illustrations, by applying to it the initial part of the sentence where the engraver was mentioned. That is, Llaguno omitted to mention the statement about Giolito, which appears interpolated in the text. The whole sentence and notes on pp. 428-29 of Vol. III in the Bottari edition (1759-1760) with the Giolito interpolation between bars reads:

[p.428] And who cannot see without amazement the works by Francesco Marcolini de Forli? Who, besides other things, printed the book of Giardino di pensieri in wood, placing in the beginning a sphere of astrologer, and his head after the design by Giussepe Porta ${ }^{1}$ da Caste nuovo della Garfagna- [p. 429] na; in that book are represented several fancies, Fate, Envy, Calamity, Timidity, Praise, and many other similar things that were considered very beautiful. II

Nor were less appreciated the figures that Gabriel Giolito, printer of books, put in the Orlandi Furiosi; because they were done in fine carving. II

1 Giussepe Porta was called del Salviati because he was a student of Cecchino Salviati. See his life in the Ridolfi in c. 221, part 1. 


\section{Indentity of the Artists involved in Vesalius's Fabrica, 1543}

In the same way as the eleven large plates on Anatomy made by Andrea Vesalio, and designed by Giovanni di Calcare' Fleming, most excellent painter, which were afterwards reproduced in small folio, and engraved in copper by Valverde, who wrote on Anatomy after Vesalio.

Llaguno, furthermore, altered the text in quoting Bottari's note, because Bottari did not say that the Vesalian drawings were attributed to Titian, but that Jan Steven van Calcar's style was so much like that of Titian and Raphael that it misled the learned. On the other hand Bottari's note stated that Jan Steven van Calcar engraved in copper, worked in wax and clay, facts which are far from established.

Still on the subject of annotations to Vasari, those in his definitive edition (1880) by Milanesi referring to Jan Steven van Calcar mentioned some other common errors:

(3) His name was Giovan Stefano di Kalkar [Jan Steven van Calcar]; therefore the error in Ebert and other authors, that Giovan Stefano [Jan Steven] had made the designs for the Anatomy by Andreas Vesalius, and Giovanni di Kalkar [Jan van Calcar] the woodcutting, although both are the same person. (The first edition [of Vesalius's Fabrica] is of Basle in 1543 in fol.). He [Jan Steven van Calcar] also made the drawings for 9 larger plates in the Epitome Vesalii (Basilea 1543 in fol.). Six similar tables which do not seem to be the same as above mentioned, were printed in Venice in 1568 [i.e. 1538] in-fol. These two last publications are very rare. See L. Choulant . . . and the Weigel Catalogue No. 18707.

At this point it is worth recalling that besides the above-mentioned quotation on Vesalius, Jan Steven van Calcar and Valverde, Vasari (1568) stated definitely once more van Calcar's authorship of the plates in the Vesalius Fabrica in Vol III, p. 818 where we read:

... Although many were staying with Titian to learn, and great was their number, we cannot say they were disciples because he did not teach many, only to a few, and were less those capable of grasping the style of Titian's work. Among those with him there was one Giovanni Fiamingho [i.e. Jan Steven van Calcar] who was praised by his teacher for his figures both small as well as large, and he was marvellous with portraits, as may be seen in his works at Naples, where he lived for some time and where he finally died. By this man (they are going to honour him for all time) were the designs of Anatomy, that were engraved and sent abroad, by the most excellent Andreas Vesalius.

Again, in the same volume III, p. 858 (1568) Vasari wrote:

I knew also in Naples and was my close friend the year 1545, Giovanni di Calker [i.e. Jan Steven van Calcar] very rare [his work] and so acquainted with the Italian style that his works could not be known were drawn by a Flemish hand, but he died young in Naples, when great things were expected from him: he designed the Anatomy for Vesalius.

The strongest objection to this testimony by Vasari was put forward by O'Malley (1964) in pp. 124-27 of his definitive biography of Vesalius under ' $\ldots$ the suspicion that its inclusion in 1568 represents the rambling reminiscences of an old man ...'; but Vasari was at the most fifty-six years old when he wrote the additions to the 1568 edition of Le Vite. Singer's comment that Vasari used the Italian word opera as

2 Gio di Calcar city in the Duchy of Cleves, studied under Titian and imitated his style and that of Raphael to the point of misleading the learned. He engraved in copper, worked in wax and clay, and died in Naples in 1546. Sandrart in Book 3, part 2, cap. 6, inserts his portraits. He says about him: [in Latin] 'The effigies of all the Italian painters, sculptors and architects, appearing in Vasari's work, which hardly could be improved, were executed by him [Jan Steven van Calcar]'. 


\section{Francisco Guerra}

a singular noun, and therefore applicable to only one of his works, is contrary to its usual collective meaning. Furthermore, the remark by Vasari that van Calcar 'died young', at the age of forty-seven, is taken as an indication of Vasari's vagueness, but it could really be accepted as the genuine expression of grief about a colleague of rare gifts and great expectations; after all, Titian, who was van Calcar's teacher, lived to be nearly 100 years old. It is, on the other hand, true that Vasari referred to '. . . eleven large plates of anatomy ...' when there are actually fourteen muscular plates and three more for the skeleton. But indeed, it is difficult even for professionals to give the exact number of full-page woodcuts of any book, unless it is handy and the plates actually counted, and no one should expect an artist to collate the number of plates in the Fabrica while writing his own memoirs. O'Malley (1964) concludes that ' ... We are privileged to decide that the statement refers to the [six] Tabulae anatomicae of 1538'. It seems more sound to believe that Vasari was referring to the Fabrica plates, because since its publication in 1543, any expression about Vesalius's anatomy, or Vesalius's book are always taken as a synonym of Vesalius's Fabrica 1543. Besides, Vasari definitely stated that the drawings by van Calcar were engraved and the blocks sent from Venice to be printed abroad, and that only happened with the plates of the Fabrica.

Vasari's emphasis on the close friendship established with van Calcar at Naples in $\mathbf{1 5 4 5}$ has overshadowed the fact that their acquaintance stemmed from an earlier date, because Vasari according to Casali (1861) and Vasari's other biographers had spent thirteen months in Venice during the years 1541-1542, and had stayed with Titian. Therefore Vasari's repeated statements that Jan Steven van Calcar was the draughtsman of Vesalius's Fabrica arose, not from hearsay, but from the fact that he was in Venice and in direct contact with the artist while the anatomical drawings were prepared and the blocks cut. This sojourn in Venice, until the winter of 1542 makes more significant any interpretation of Vasari mentioning Marcolini as the engraver. Le Vite, furthermore was not the vague story of a rambling artist, but the vivid account of a man who searched with eagerness the lives and works of his colleagues. Vasari's information is so reliable that the suggestions or opinions expressed at a later date by Ridolfi (1648), Bonavera (1670), Tortebat (1667), Maschenbauer (1706), Caro (1821) and A. F. Didot (1863) about Titian being the Vesalian draughtsman can be discarded as groundless.

\section{NEWS FROM SANDRART AND OTHERS}

Llaguno's quotation is also important because Bottari's note leads to a chain of references indicating the early tradition that established Jan Steven van Calcar's authorship of the Vesalian drawings. Although Bottari (1759-1760) referred to Sandrart's books (1675 and 1683), this reference can in fact be traced to a much earlier date. Joachim von Sandrart [1606-1688], a great painter in his own right, earned his reputation, like Vasari, by publishing excellent biographies of German painters which are particularly quoted for news of his contemporaries. In appraising Sandrart's information about Jan Steven van Calcar it is worth remembering that Sandrart was extremely interested in Titian and his circle, and this was the reason for his journey from Germany to Venice in 1627 and for his return there in 1635; 


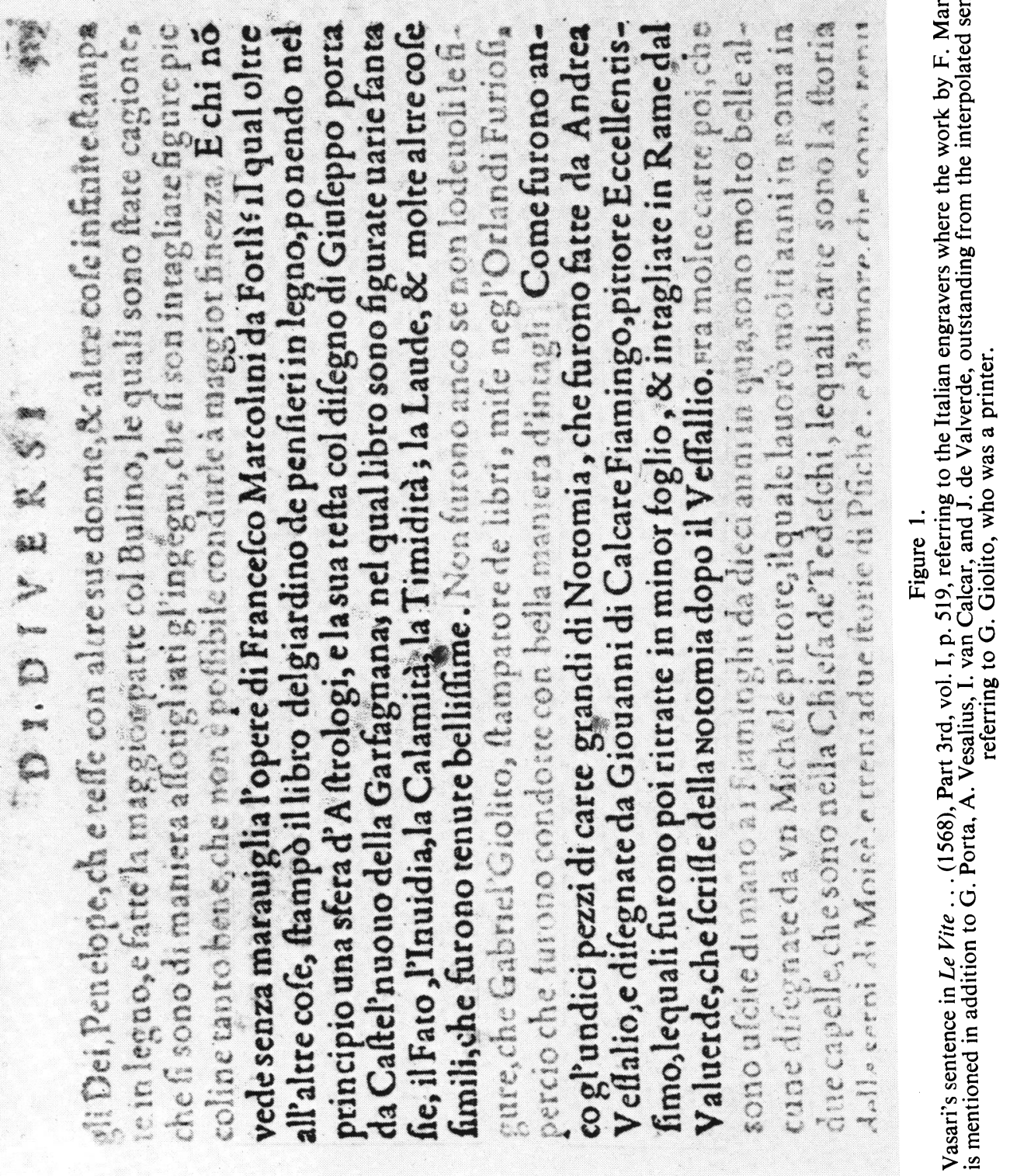





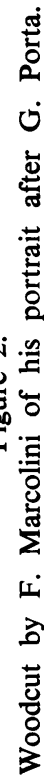




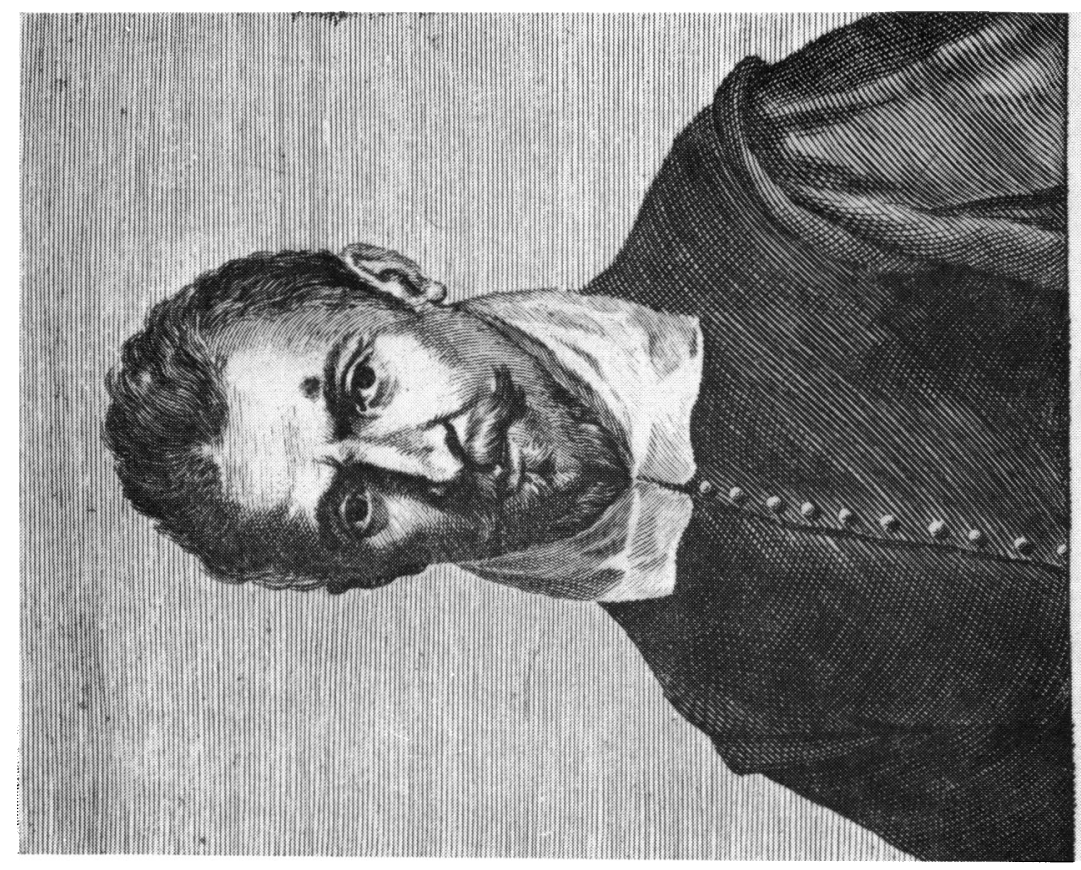

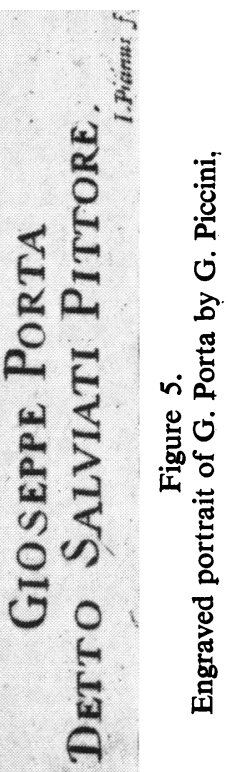

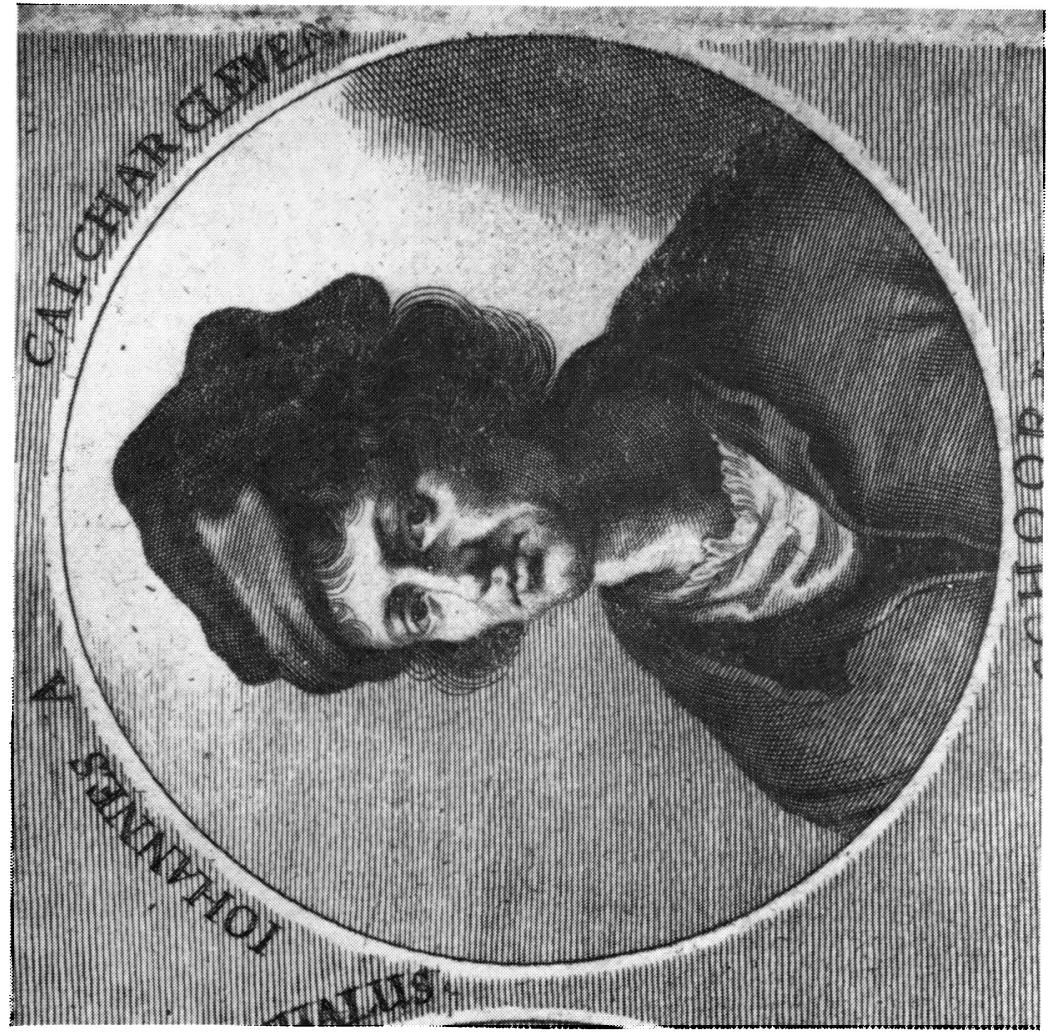

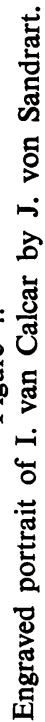




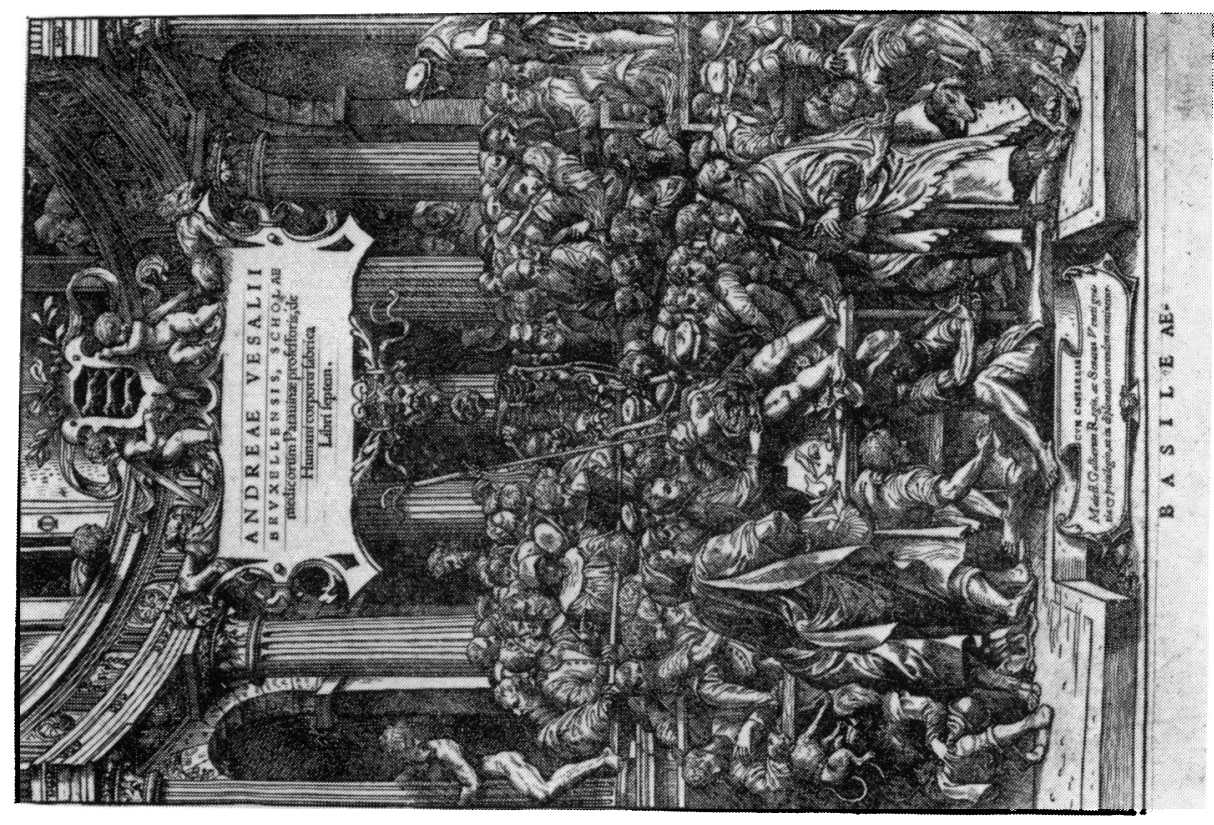

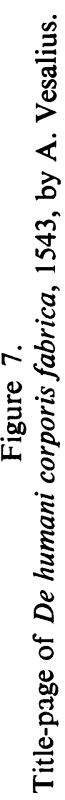

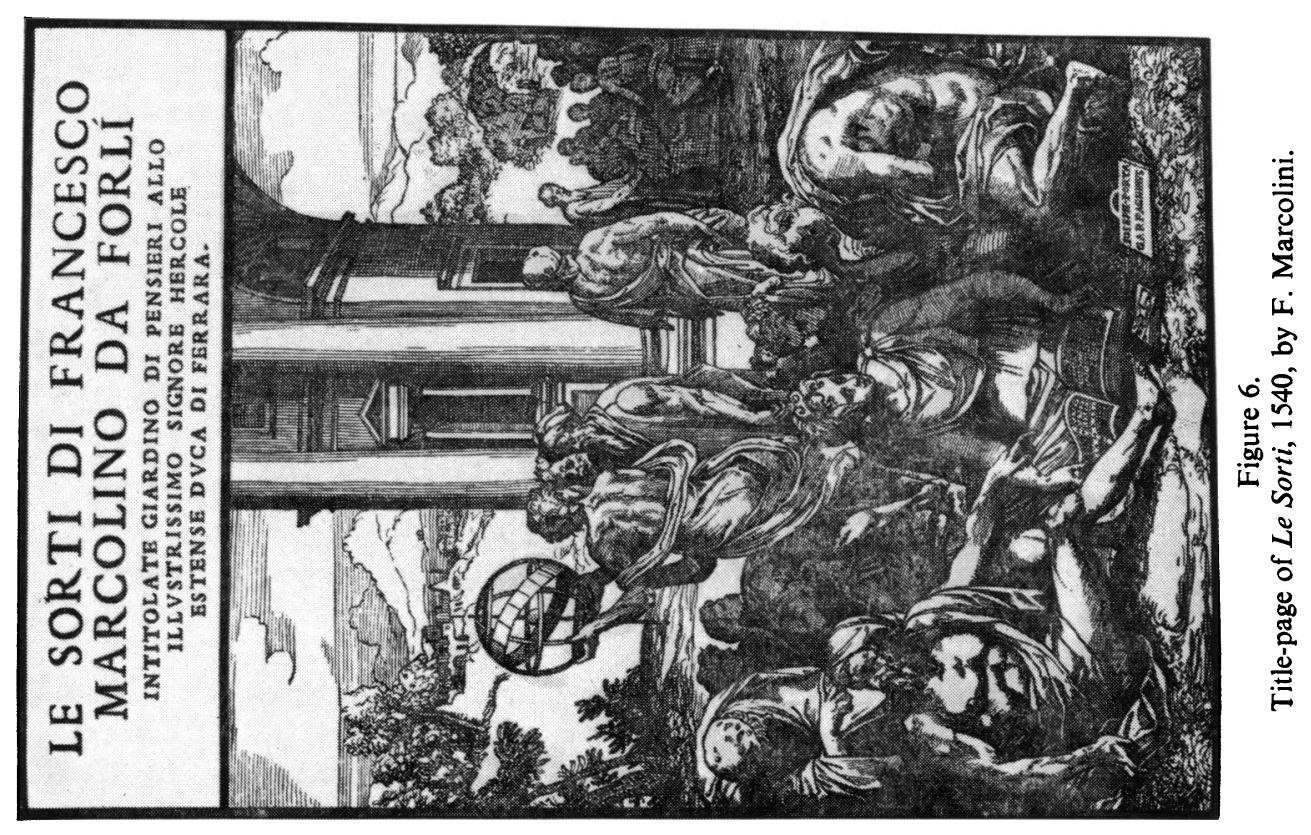


he was, therefore, knowledgeable about Titian's environment. Sandrart's books, both the German edition [1675-1679] and its Latin version (1683), have a similar text for the life of Jan Steven van Calcar:

\begin{abstract}
... Among all those the nature favoured, that one among the Dutch that I see truly chosen to silence the Italian's pretension that no Fleming could overtake, not even equal their masters in the design of human figure, it is Jan [Steven] van Calcar, of whom I cannot say loud enough his merit, and about whom I regret to have so little information ...

... In Venice [Jan Steven van] Calcar was a brilliant disciple of the great Titian and adopted his style to the point where it was not possible to distinguish their works. Goltzius, whose testimony I accept, entirely, being in Naples, had the opportunity of examining certain portraits that he declared had to be by Titian. The artists told him: 'You are right but they are not by Titian but by Jan [Steven] van Calcar whose style is so much like the master's that the most learned make the same mistake.' According to Vasari, who knew him in Naples, he could not be included among the Flemish. He had, particularly with pencil and pen, a special talent, worked by powerful strokes, and this is why it was difficult to distinguish him from Titian. It was he who designed for Vesalius's Anatomy, that precious work where the plates, extremely well done, are sufficient to give him eminent rank among the Dutch . . . He died in 1546 at Naples, not very advanced in age.
\end{abstract}

The introductory biographical note by von Sandrart (1675) sounds very much the same as that found in Carel van Mander's (1548-1606) Lives of Dutch Painters (1604), published many years earlier.

Indeed, Sandrart's statement that Jan Steven van Calcar made the drawings for Vesalius's anatomical work must refer to the Fabrica 1543, because the fame of this book had completely eclipsed that of Vesalius's Tabulae 1538, which we already know was produced by Jan Steven van Calcar. However, Sandrart, like van Mander and Papillon (1766), followed this true statement with the assertion that Jan Steven van Calcar was also the author of the portraits of the Italian painters, sculptors and architects depicted in Vasari's Le vite 1568 and this seems to be in conflict with the facts. The first edition of Vasari's Le vite appeared in 1550, without any portrait, and even without any mention of Jan Steven van Calcar, though he seems to have died at Naples in 1546, and Vasari dealt in his book with deceased artists. The second edition of Vasari's Le vite, with the engraved portraits, and praising the memory of Jan Steven van Calcar, appeared in 1568, that is to say when the Flemish artist had already been dead for twenty-two years. On the other hand Vasari had acknowledged in the introduction (1568) that the drawings for the portraits had been sent to him by friends from different places and even that the engraver, Cristoforo Coriolano, had executed the work away from Florence.

Most of the biographical data on Jan Steven van Calcar and his relationship with Vesalius has been surveyed by de Feyfer (1933), but he was unable to alter the Vesalian indoctrination that is found among medical historians, since Roth (1892) published Vesalius's biography. Cushing (1943 and 1962) accepted de Feyfer's findings and it is to be regretted that the true nature of certain title-page drawings of Vesalius's Fabrica, purportedly by J. Steven van Calcar, was not then disclosed. In point of fact all these authors missed an interesting reference to this controversial issue. Oppenheim \& Co. of London published (December 1929) an Illustrated Catalogue No. 177, second series, in which appeared the following item: 


\section{Francisco Guerra}

94. Vesalius (And). The original six drawings for the Six plates to Tabulae Anatomicae 1538, by John Stephan de Calcar, each signed, with letters and testimonials bearing on their authenticity, folio sizes, in fair condition, $£ 700$.

From that very catalogue the late Sir Henry Wellcome purchased several items, but not the Vesalian drawings. Oppenheim \& Co., a firm founded in 1888 , is still in business, but unfortunately the records of the firm were destroyed during the air-raids on London and the present existence and location of the drawings cannot be established. These drawings cannot be those advertised at the sale of Dr. Richard Mead of London (1745), 'Item 68 Vesalius's original anatomical drawings neatly bound in red morocco and gilt . . ., because they were purchased by William Hunter on 20 January 1755 for $£ 2716 s$. $6 d$. and are now with the Hunterian Collection at Glasgow. There are many other references supporting the assertion that van Calcar designed the plates of the Fabrica, but they all stem from Vasari's news and have little to add to it.

\section{VESALIUS'S CREDIT TO JAN STEVEN VAN CALCAR}

The name of Jan Steven van Calcar (Joannis Stephans Calcarensis) appears as the publisher (Sumptibus) in the colophon of Vesalius's Tabulae anatomicae sex, Venice 1538. This awkward role of J. Steven van Calcar seems somehow clarified in Vesalius's dedication of the Tabulae to Narcissus Parthenopeus [i.e. N. Vertunus] on table I, where he wrote,

... I made on a sheet of paper a hasty sketch of the veins ... and I have added new plates in which Johannes Stephanus [i.e. Jan Steven van Calcar] a remarkable painter of our time, has very properly expressed [the skeleton] on three postures.

There is no doubt, therefore, of van Calcar's participation in the drawings of the Tabulae anatomicae 1538, and the technique he followed to make the illustrations from a skeleton mounted by Vesalius, like the one still preserved in the University of Basle. Furthermore, we know that in the same year in Padua, after returning from his trip to Bologna, Vesalius in the venesection Epistola, 1539, to Nicolaus Florenas (i.e. N. Herco) restated his relationship with van Calcar. ' . . . We have now completed two plates of the nerves also ... I think I ought to keep them until the time when I work on the plates of the muscles and the internal parts ...' Vesalius's concluding words are very similar to those he used referring to van Calcar in the Tabulae. '. . . and if Jan Steven van Calcar, the most remarkable painter of our time does not refuse his assistance ...' In this phrase Vesalius acknowledged the paramount role of Jan Steven van Calcar in the Fabrica, not just his artistic distinction. No better testimony can be produced to assess the part played by the physician and the part played by the draughtsman in the Fabrica. Since 1539, therefore, Vesalius was working at Padua in close contact with van Calcar, commuting a few miles away from the Titian studio in Venice. They had already solved the illustration problems pertaining to the skeleton and the circulatory system which they used in the Tabulae 1538, and Vesalius stated in an irrefutable testimony that they had finished two plates of the nervous system and were contemplating the drawing of the muscles and the internal organs. It was in Venice that the cycle of the production of the Fabrica is again closed, because Vesalius sent from that city on 24 August 1542 the letter to his printer 
Identity of the Artists involved in Vesalius's Fabrica, 1543

in Basle, Joannes Oporinus, accompanying the woodblocks which had been packed in Venice under the care of Nicolaus Stopius, the representative of the Bomberg house in Venice.

\section{MARCOLINI THE ENGRAVER}

Francesco Marcolini or Marcolino [c. 1505-c. 1560] who, Llaguno states -in his quotation from Vasari -was the engraver of Vesalius's Fabrica 1543, was a wellknown craftsman in the history of Venetian printing, although many aspects of his life, including his dates of birth and death, have not been established. Born in Forlí, Marcolini went to Venice in 1527 and by 1535 was operating a printing shop; the first issue, according to Zaccaria (1850), was La Cortegiana by Pietro Aretino (14921556). Contrary to Bottari's opinion expressed in the Lettere pittoriche (1754-1768), in which Marcolini is called ' . . . an ignorant printer of obscure name . . ., perhaps due to Bottari's position in the Vatican and the licentious books printed by Marcolini, Vasari (1568) thought very highly of him as an engraver, and Bonoli (1661) went even further considering Marcolini ' . . . a great draughtsman, woodcutter and highly skilled printer of books'. Servolini (1953), in the recent introductory study for the reprint of Casali's monograph on Marcolini (1861), shows that he was an author, engraver, architect and engineer, as well as a printer. The manuscripts of Marcolini's mathematical and architectural studies, the bridge he built between Venice and Murano, and the books he printed, speak for themselves. The success of his publishing business overshadowed any other activities and was due in great part to his handling of Aretino's works up to 1545. After 1550 Marcolini printed mostly the works of Antonio Francesco Doni (1513-1574). Among the titles issued in his shop were the celebrated musical books in movable type, and books on architecture, such as the editions of Vitruvius, Serlio, and others.

The role of Marcolini in Vesalius's Fabrica begins to make sense when it is found that he was not only engraving in Venice during the years Vesalius spent preparing that book, but becomes even more significant, when it is established that Marcolini was one of the best friends - amicissimo e compare - of Titian and in close contact with Titian's disciples. The portrait of Aretino, another of Marcolini's godfathers, was painted by Titian at the request of Marcolini; he was also a friend of Vasari, Salviati, Sansovino and many other artists, and there is no reason to exclude his acquaintance or friendship with Jan Steven van Calcar, who was one of Titian's best pupils. Pietro Aretino, it must be pointed out, played an important role in Marcolini's life, not only because the printer's early success was based on the monopoly, for all practical purposes, of Aretino's works, but because Aretino had an amorous liaison with Isabella, the wife of the printer which Marcolini discovered in 1545, leading to his departure for Cyprus. However, Aretino, in a later edition of La Cortegiana, still refers to Marcolini with praise and compares him with Raimondi who was the greatest engraver of that period. ' . . I I do not deny that Marcantonio [Raimondi] was not unique with the burin ... and so was full of virtues, flourishing with talent, Francesco Marcolino from Forli.'

Marcolini returned from Cyprus in 1550, but in 1559 left Venice for Verona and no record can be found of his life after that date. 


\section{Francisco Guerra}

\section{THE CALENDARS OF MARCOLINI AND VESALIUS}

In order to test the validity of Llaguno's interpretation of Vasari's text, a check could be made on Marcolini's working schedule while Vesalius and Jan Steven van Calcar were preparing the texts and drawings for the Fabrica. The activities of Marcolini in Venice between the years 1530 and 1545 can be followed in the catalogue of the books he published, which was first arranged chronologically by Zaccaria (1851), afterwards enlarged by Casali (1863), and reprinted with notes by Servolino (1953). It is doubtful whether Marcolini printed books Nos. 1 and 2 in 1530, or Nos. 3 and 4 in 1534. There is evidence, however, that in the year 1535 the press of Marcolini printed books 5 to 7; in 1536 Nos. 8-19; in 1537 Nos. 20-27; in 1538 Nos. 28-37; in 1539 Nos. 38-50; in 1540 Nos. 51-56; in 1541 no books seem to have been printed; in 1542 there is doubt whether Nos. $57-66$ were actually printed; in 1543 Nos. 67-72; in 1544 No. 73; and in 1545 Nos. 74-76. In the calendar of Marcolini's printing schedule, according to Zaccaria (1850), a gap in production becomes apparent from the latter part of 1540 to the middle of 1542 which tallies with the period when the blocks for Vesalius's Fabrica 1543 were engraved in Venice, and this coincidence is too great to be accidental.

Due to the close friendship of Marcolini with Titian and his disciples, van Calcar and Vesalius had to consider Marcolini from the start as the potential engraver for the Fabrica, because all the contemporary sources - Vasari, Aretino, Barbaro, Doni, Brusantino - praised his work and some thought it was second only to Marco Antonio Raimondi [1480-1530] the great engraver of the Italian Renaissance. Furthermore, Marcolini published precisely in 1540 - while Vesalius and van Calcar were preparing the drawings - the book that gave lasting fame to Marcolini as an author, as a draughtsman, as an engraver, and as a printer. The book in question was also mentioned by Vasari (1568) in referring to engravers, Le Sorti . . . intitolate Giardino di pensieri (1540); this illustrated book by Marcolini was reprinted many times during the author's lifetime and even after his death. The title-page of Marcolini's Le Sorti, 1540, had an architectural background, so many times treated by Marcolini both as an architect and printer of architectural books, that makes not accidental the fact that Vesalius expanded the theme when van Calcar purportedly drafted the title-page for the Fabrica 1543. The bearded profile portrait of Marcolini engraved by himself after the drawing by Giuseppe Porta, according to Vasari (1568) - although Servolini (1953) points out it could be by Titian - also resembles Vesalius's engraved portrait for the Fabrica, and was used as an illustration in the books by Doni (1552). Even the texture and vigour of the woodcuts both in the Fabrica and Le Sorti offer many similarities, as does the lettering in both portraits.

Due to Vasari's (1568) mention of Giolito's engravings next to Marcolini's - a sentence that has also puzzled Casali (1861) - it is important to study the work of Gabriel Giolito de Ferrari [c.1510-1578], who was Marcolini's contemporary. Bongi (1890-1895) has surveyed in detail the issues of Gabriel Giolito from 1541 to 1578. Giolito was not an engraver, but a publisher who sometimes even had to borrow the type and had woodblocks cut for the Orlando Furioso, the Decameron, the works of Petrarch, and the Transformazioni by Dolce; but a comparison, for instance, of the woodcuts in the twenty-eight editions by Giolito of the Orlando Furioso between 
Identity of the Artists involved in Vesalius's Fabrica, 1543

1542 and 1560 shows that none of them resembles the woodcuts in the Fabrica or Le Sorti. The style of Giolito's engravers is finer, more delicate, while both Le Sorti and the Fabrica have larger and stronger tracing. Therefore it can be stated that Giolito had no connection with Vesalius's Fabrica and that the interpretation of Vasari's text about the draughtsmen and the engravers of the Fabrica's plates by Llaguno was entirely justified.

\section{MARCOLINI'S CRAFTSMEN}

In accepting as correct Llaguno's statement from Vasari to the effect that Francesco Marcolini was the engraver of Vesalius's Fabrica one weak point becomes apparent. Despite the thoroughness of Zaccaria (1850), Casali (1861) and even the revision of the latter by Servolini (1953), bibliographical works of that nature are always liable to omissions. Marcolini is known to have printed over 150 books, and some of his musical printing was not registered. Other books, particularly those of a licentious character or those dealing with astrological predictions - the books of Aretino or fortune-telling by Marcolini himself, were in precisely that category - had been forbidden on occasion and circulated without imprint, though licensing by the Inquisition was not started in Venice until 1547. In point of fact, further research into the books printed by Marcolini during the critical years 1540-1542, when Vesalius prepared the Fabrica 1543, has brought another book to light, Pietro Aretino's La Vita di Catherina Virgine in 1541, and there is another book of which the printing can be called in question. However, this find does not basically alter the fact that Marcolini and his craftsmen ceased printing for over a year and were engaged in another pressing and absorbing task. The three hundred and twenty-three woodcuts in the Fabrica more than justify the long process of engraving and the well-known impatience of Vesalius about the craftsmen.

But to add to the thrilling mystery of the Vesalian artists, at the juncture when their identity seemed to have been solved, the trail leads to another incognita. Marcolini employed another engraver of German extraction in his shop while the Fabrica blocks were being cut. The name of Giovanni Britto [i.e. Johann Britt or Breit] appears in the imprint of the book by G. Servilio, La congiuratione de Gheldresi contra la cittá d'Anversa, printed at Venice in Marcolini's shop in October 1543.

G. A. Moschini [1773-1840] in his study on Venetian woodcutting (1926) stated that Johann Britt was the manager of Marcolini's woodcutting shop. A few samples of his work can be traced, i.e. the portrait of Charles V, the Adoration of the Shepherds, and a portrait of Titian which Pietro Aretino received. In the letter acknowledging its arrival, Aretino referred to Johann Britt as 'the German who engraves in Marcolini's shop'. Britt's signature was B., G.B. Intagliatore or a cube as his monogram, but unfortunately, as has already been stated, no monograms appeared in the Fabrica. However, there is a fact of extraordinary significance in Britt's work: the printing of the Congiuratione de Gheldresi ended in October 1543. This little book was produced in Marcolini's shop after the Fabrica's plates had been shipped from Venice to Basle in August 1542, and for the first time the obscure engraver appeared then as a publisher. This new status demanded not only the use of Marcolini's press, but in order to cover the expenses of book production, engraving of plates, and the purchase of 


\section{Francisco Guerra}

paper, ink, leather and boards, Britt must have received a substantial payment. The completion of the woodcuts for the Fabrica and the settling of accounts by Vesalius fit so well with Marcolini's working schedules and Britt's receipt of money that this dovetailing cannot be brushed aside.

After studying the works of the Venetian draughtsmen and engravers grouped around Titian between 1540 and 1542, it is difficult to exclude Porta from those who cut illustrations for Vesalius's Fabrica. Giuseppe Porta, known as Salviati the younger [1520-1570] was born in Castelnuovo della Garfagnana, Modena, and was orphaned at an early age. He was adopted by the Florentine painter Francesco de Rossi, known as Cecco Salviati because Rossi had received the protection of Cardinal Salviati. Porta was better known for his paintings and frescoes at the Library of St. Mark in Venice, and in several residences and churches, and his work was much praised by Titian. But soon after arriving at Venice, Porta began to cut xylographic decorated capitals for Marcolini's press and produced the large woodcut plate, which he signed in full, for the title-page of Marcolini's major work Le Sorti, 1540. That date also marks the year in which engraving of the plates for the Fabrica began. Porta continued to work at Marcolini's shop where he produced beautiful woodcuts for other books, particularly those on architecture, such as the one on the Ionic column printed by Marcolini in 1552.

The suggestion that Porta engraved for the Fabrica had already been made by Sotzmann (1850) in a study on medieval books of fortune-telling in which he discussed Marcolini's Le Sorti 1540. Sotzmann (1850) considered the title-pages of both Le Sorti 1540 and the Fabrica 1543 to have been engraved by Porta, and this suggestion was quoted by Choulant (1852) without comment. Only now, after defining the role of Marcolini and Britt in the engraving of the Fabrica, can Sotzmann's ideas be properly appreciated. Of course, the statement made by Osiander (1799) to the effect that Oporinus designed the title-page, accepting the evidence of the monogram with the initials $\varnothing$, is now known to be incorrect, as is his assertion that the stroke among the plants at the bottom of the seventh muscle plate of the Fabrica can be accepted as the monogram $\mathrm{D}$ for the engraver.

Finally it would be convenient to eliminate the possibility of some other Venetian engravers carving the blocks of the Fabrica between 1540 and 1542. The task is difficult because there were many engravers, not all of whom have left records, but in fact the work of the finest craftsmen is known, and only one of these men could have been selected for the job by Vesalius and van Calcar. Sebastiano Serlio [14751554], a native of Bologna only worked in Venice until 1541 and then left to paint at Fontainebleau. Agostino dei Musi, known as the Venetian [c. 1490-1540] was the most important to eliminate because, according to Lomazzo (1584), he had achieved the greatest excellence in the woodcutting of anatomical plates; but he was in Rome until 1527, fled to Bologna and Florence during the pillage of Rome, returned there in 1531, and he died in Rome while the plates of the Fabrica were carved. Niccoló Baldrini [1510-1566] the woodgraver from Vicence might have been engaged on the plates, but there is no record of his work in Venice at the time, and his name has never been connected with Vesalius. Giovanni Battista Franco, known as Il Semolei [c. 1510-1580] was indeed a painter and engraver, but he was working in Florence 
and Rome in the years in question and went to Venice in 1579. Martin Rota or Kolunic-Rota [c. 1520-1583] followed the style of Michelangelo, Raphael and even Titian; engraved both in Rome and Venice, but his Venetian work can only be dated after 1568, far too late to be related to Vesalius. Also late is Cesare Vecellio [c. 15211601] whose work as an engraver appeared after the middle of that century. Domenico dalle Greche [fl. 1546] began to be known by his works as an engraver years after the printing of the Fabrica. Girolamo Porro [1520-1604] pupil of Enea Vico in Parma, did not work in Venice until after 1586. The other great Venetian engravers, Agostino, Vavassore, Fontana, the two Bertelli, Cort, Guerra, Sanuto and the rest, flourished too late to be considered. We are, therefore, left with the Marcolini shop, Francesco Marcolini, Johann Britt and Giusseppe Porta, about whom we have positive information.

\section{DISCUSSION}

Roth (1892) and subsequent biographers of Vesalius have praised him so highly in the history of anatomy, that the predecessors and contemporaries, to say nothing of those who succeeded him, have been cast into the shade. So often a historian's absorption in a given character and his accomplishments has led to the disregard of other cultural forces which have been operating simultaneously towards the same objective. Similar factors have influenced the role of Vesalius in the evolution of anatomy in Italy during the first half of the sixteenth century.

The sources of that period emphasize that painters, sculptors and engravers were passionately trying to master the representation of the human figure. The Italian cities witnessed the arrival of artists from every corner of Europe, to study hour after hour, for years, the contour and texture of the human body, at any age, in any posture, with every detail. The artists copied paintings and statues of the masters, but they also filled the dissecting rooms of Santo Spirito, Bologna and Padua. Compared to them, the physicians and surgeons played a very minor role.

Long before Vesalius published the Fabrica, 1543, the illustration of the human body had been treated by Marcantonio Raimondi, who engraved such disparate subjects as the obscene drawings by Giulio Romano and religious scenes from the Holy Scriptures. Furthermore, Lomazzo (1584) disclosed that Baccio Bandinelli [1488-1560] had produced unsurpassed designs of human anatomy which had been beautifully engraved by Agostino Veneziano. Drawings of human anatomy could then be found, as they are now found, in the portfolio of every artist. A survey of the engraving techniques of this early period shows that the most delicate problem to be solved was the representation of muscular fibres, which Vesalius and van Calcar were unable to produce in the Tabulae 1538. For this reason, as already pointed out (1967), the muscular plates [1541] by Giambattista Canano indeed deserve much wider recognition.

The interpretation given by Llaguno to Vasari's text is in fact a reminder of the fluid syntax of that period, besides the guiding reference to the Vesalian artists. The inaccuracies to be found in Vasari when his literary style is examined according to our own grammatical canons, is a pointer to be kept in mind while the search for factual information goes on, and above all during the assessment of the historical data. To judge the human values of that period, or just to apply our rigid rulings to 


\section{Francisco Guerra}

Vasari's text, is like expecting to find metric system markings in the jugs of wine drunk by Vasari in the Venetian taverns.

The tedious quotation, logical reasoning, and objective analysis that must prevail in a search of this nature, must unfortunately be unimaginative, but only to a certain degree. Furthermore, historical research tends to leave aside the human aspects of the characters playing a role in the publication of the Fabrica, and it is precisely human life which makes history interesting. Every name connected with the making of the Fabrica has a fascinating story in hiding. The life of Vesalius has been told many times in its academic greatness, in which the arrogance of youth found penitence in the jealousy of elders, but the romance of the artists is much less known. Jan Steven van Calcar, we learnt, eloped with the daughter of the innkeeper who had plotted his murder; Van Calcar married the girl who had discovered the plan and saved his life. The career of Francesco Marcolini da Forll collapsed when he discovered that one of his legal progeny was not after all the godson of the debauched Aretino, but probably Aretino's own natural son.

Vasari never had much liking for the Venetian artists-they favoured colour instead of line-but even so, he left for us the names of the Fabrica's illustrators, because anyone who is familiar with the behavioural patterns of artists will realize that no work of the nature of the Fabrica could have passed unnoticed to Vasari during his sojourn in Venice. He went there seeking information, as he moved all through Italy visiting every living artist of any merit; this is why his legacy was $L e$ Vite. Little imagination is needed to visualize the discussions of Vasari and van Calcar over the drawings of the Fabrica; and with more imagination we can almost smell the garlic exhaled by Marcolini while discussing the carving of woodcuts with his compare Vasari, or hear the clatter of mules over cobbles and the voice of Vasari bellowing at the muleteers as they left Venice with the plates of the Fabrica.

\section{COROLLARY}

Almost two centuries ago Llaguno interpreted the testimony of Vasari regarding the artists involved in producing Vesalius's Fabrica to mean that the designer had been Jan Steven van Calcar and the engraver Francesco Marcolini da Forli. Although Vesalian scholars have known of Vasari's evidence for many years, the true and full meaning of the testimony had never been grasped. Vesalius, on the other hand, confirmed that van Calcar had finished the two drawings of the nervous system and was expecting to proceed with those of the muscles and internal organs; the problem of making the drawings for the skeleton and the vascular system had already been solved jointly by them in the Tabulae 1538. Vasari was within the Titian circle at Venice, which included both van Calcar and Marcolini, at the time that the cuts were carved and unequivocally stated that they were sent abroad. A careful analysis of the work of Marcolini and his craftsmen, Johann Britt and Giusseppe Porta, between 1540 and 1542, confirms that Llaguno was correct in his interpretation of Vasari.

The publication of De humani corporis fabrica 1543 brought for Andreas Vesalius the honour of being considered the founder of modern anatomy. That distinction must now be shared by the artists Jan Steven van Calcar and Francesco Marcolini da Forlí who made of the Fabrica one of the great books of all time. 
Identity of the Artists involved in Vesalius's Fabrica, 1543

\section{REFERENCES}

Aretino, Pietro, Strambotti a la Villanesca, Venice, F. Marcolini, 1544.

BALDINUCCI, FilipPo, Cominciamiento, e progresso dell 'arte dell' intagliare in rame, colle vite di molti di più eccellenti maestri della stessa professione, Florence, P. Matini, 1686.

Bongi, Salvatore, Annali di Gabriel Giolito de' Ferrari da Trino di Monferrato, stampatore in Venezia, Rome, Tip. Giusti, 2 vols., 1890-1895.

Bonoli, PaOLo, Istorie della cittd di Forli, intrecciate di varii accidenti della Romagna e dell' Italia, Forli, Per li Cimatti, e Saporetti, 1661.

BOTTARI, GIOVANNI G. (Ed)., Raccolta di lettere sulla pittura, scultura ed architettura scritte da' piu celebri Professori che in dette Arti fiorirono dal secolo XV. al XVII, Rome, Eredi Barbiellini, 6 vols., 1754-1768.

Brusantino, Vicrnzio, Angelica Inamorata, Venice, F. Marcolini, 1550.

Brusantino, Vicenzio, Angelica inamorata, Vinegia, F. Marcolini, 1553.

CASALI, SCIPIONE, Annali della Tipografia Veneziana di Francesco Marcolini da Forli, Forli, Matteo Casali, 1861.

CASALI, SCIPIONE, Annali della Tipografia Veneziana di Francesco Marcolini da Forli . . . Introduzione di Luigi Servolini, Bologna, Alfredo Gerace, 1953.

CHOULANT, LUDWG, Geschichte und Bibliographie der anatomischen Abbildung nach ihrer Beziehung auf anatomische Wissenschaft und bildende Kunst, Leipzig, R. Weigel, 1852.

Don, ANTONIo Francesco, I Marmi, Vinegia, F. Marcolini, 1552.

Doni, Antono Francesco, I Mondi (Inferni), Vinegia, F. Marcolini, 1552.

Doni, Antonio Francesco, Novelle di Messer Antonio Francesco Doni, edited by Bartolommeo Gamba, [Venice], [Tipografia di Alvisopoli], 1815.

Don, Antono Francesco, la seconda libraria del Doni, Venice, F. Marcolini, [for Gualterio Scotto], 1551.

Doni, Antono Francesco, La seconda libraria del Doni, Vinegia, F. Marcolini, 1555.

FeYFeR, F. M. G. de, 'Jan Steven van Calcar (Johannes Stephanus) 1499-1546'. Nederlandsch tijdschrift voor geneeskunde, 1933, 77, 3562-79.

Gamba, Bartolomeo, Delle lodi di Luigi Cornaro. Discorso, Venezia, Tipografia Picotti, 1817.

Guerra, Francisco, 'Juan de Valverde de Amusco. Evidence for the identification of his portrait-claimed to be that of Vesalius-with a reappraisal of his work', Clio Medica, 1967, 2, 339-63.

Ivins JR., Winliam M., 'What about the Fabrica of Vesalius?' in Three Vesalian Essays to Accompany the 'Icones Anatomicae' of 1934, New York, Macmillan, 1952.

JACKSCHATH, E., 'Die Begründung der modernen Anatomie durch Leonardo da Vinci und die Wiederauffindung zweier Schriftem desselben', Medizinische Blatter, 1902, 15, 770-72.

Kristrller, Paul, 'Eine Zeichnung von Johann Stephan van Calcar, zum Titelblatte der Anatomie des Andreas Vesalius', Mitteilungen der Gesellschaft für vervielfältigende Kunst, Wien, 1908, pp. 17-24.

Llaguno y Amfrola, Eugeno, Noticia de los arquitectos y arquitectura de España . . . acrecentada con notas, adiciones y documentos por D. Juan Agustín Ceán Bermudez, Madrid, Imprenta Real, 1829.

Lomazzo, Giovann Paolo, Trattato dell'arte de la pittura, Milan, P. G. Pontio, 1584.

MANDER, CAREL VAN, Het Schilder-Boeck waer in voor eerst de leerlustighe Jueght den groudt der Edel vry Schilderconst in Verscheydem deelen wort voorghedraghen, Haarlem Paschier, Van Wesbusch, 1604.

Marcolin, Francesco, Le Sorti . . . intitolate Giardino di Pensieri, Venice. Francesco Marcolino, 1540.

MichIELS, JosEPH AlFRED XAVIER, Histoire de la peinture flamande et hollandaise, Brussels, A. Vandale, $1845-1849$.

MozhSEN, JohaN C. W., Verzeichniss einer Samlung von Bildnissen, grösstenheils berühmter Aerzte, Berlin, C. F. Himburg, 1771. 


\section{Francisco Guerra}

[MORELlI, JACOPO], Notizia d'opere di disegno nella prima meta'del secolo XVI essistenti in Padova Cremona, Milano, Pavia, Bergamo, Crema e Venezia scritta da un anonimo di quel tempo, Bassamo, s.n. 1800.

Moschetti, ANDrea, Giorgio Vasari (1511-1574), Turin, G. B. Paravia, 1935.

Moschini, Giannantonio, Dell'Incisione in Venezia, Venice, Zanetti Editore [1926].

O'MALley, C. D., Andreas Vesalius of Brussels 1514-1564, Los Angeles, University of California Press, 1964.

OsIANDER, FRIEDRICH BENJAMIN, Lehrbuch der Entbindungskunst. Litterärische und pragmatische Geschichte dieser Kunst, Göttingen, J. G. Rosenbusch, 1799.

Papillon, Jean Baptiste Michel, Traité historique et pratique de la Gravure en bois, Paris, Pierre-Guillaume Simon, 1766.

RIDOlfi, Carlo, Le maraviglie dell'arte, overo le vite degl'illustri Pittori Veneti, Venetia, Gio: Battista Sgava, 1648.

Roth, Moritz, Andreas Vesalius Bruxellensis, Berlin, G. Reimer, 1892.

SANDrart, Joachim Von, L'Academia Tedesca della Architectura, Nürnberg, J. P. Miltenberger \& S. Frobergern, 3 vols., 1675-1679.

SANDRART, JoACHIM Von, Academia nobilissimae Artis pictoriae, Nuremberg, C. S. Frobergii, 1683.

Serlio, Sebastiano, Regole generali di architettura [Libro IV], Venice, F. Marcolini, 1537.

SERVILIUS, JOANNES, La congiuratione de Gheldresi contra la citta $d$ Anversa, trad. by F. Strozzi, Vinegia, G. Britto [F. Marcolini], 1543.

Singer, Charles, 'Some Vesalian problems', Bull. Hist. Med., 1945, 17, 423-38.

Singer, Charles and Rabin, A., A Prelude to Modern Science, Cambridge University Press, 1946.

Sotzmann, Johann Daniel Ferdinand, 'Die Loosbücher des Mittelalters', Serapeum, $1850,11,49-89$.

U[NDERWOOD], A. E., 'Calcar, Wesel, and Vesalius', Brit. med. J., 1945, 1, 381-82.

VASARI, GIORgIO, Le vite de piu eccellenti architetti, pittori, et scultori italiani, da Cimabue insino a'tempi nostri, Florence, L. Torretino, 1550.

VASARI, GIROgIo, Le vite de' piu eccellenti pittori, scultori, e architettori . . . die nuovo . . . reviste e ampliatte con $i$ ritratti . . . Fiorenza, I. Guinti, 1568.

VASARI, GIORgIo, Le vite de' piu eccellenti pittori, scultori e architettori . . . corrette da molti errori e illustrate con note [by Giovanni G. Bottari], Rome, Marco Pagliarini, 3 vols., 1759-1760.

VASARI, GIORgIo, Le Opere di Giorgio Vasari . . . con nuove annotazioni e commenti di Gaetano Milanesi, Florence, G. C. Sansoni, 9 vols., 1878-1885.

Vitruvius Pollio, Marcus, I dieci libri dell'architettura, trad. by D. Barbaro, Vinegia, F. Marcolini, 1556.

Wirgand, WILly, 'Marginal notes by the Printer of the Icones', in Three Vesalian Essays to Accompany the 'Icones Anatomicae' of 1934, New York, Macmillan, 1952, pp. 25-62.

WeIGEL, RuDOLPH, Catalog von Kunstsachen und Büchern (No. 24. p. 9. no. 18707), Leipzig, R. Weigel, 35 vols., 1838-1866.

ZAcCARIA, GaETANo, Catalogo ragionato di opere stampate per Francesco Marcolini da Forli . . ravennate con memorie biografiche del medèsimo tipografo raccolte dall'au. Raffaele de Minicis, Fermo, Tip. de 'Fratelli Ciferri, 1850. 